DOI https://doi.org/10.18551/rjoas.2020-10.10

\title{
SUSTAINABILITY STATUS OF FISHERY BUSINESS IN SUPPORTING DEVELOPMENT OF COASTAL VILLAGE BASED ON AGRIBUSINESS FISHERIES IN DONGGALA DISTRICT, INDONESIA
}

\author{
Fachrudin*, Doctoral Student \\ Antara Made, Rizal Akhmad, Laapo Alimuddin \\ Department of Agricultural Science, University of Tadulako, Indonesia \\ *E-mail: fachrudin@unisapalu.ac.id
}

\begin{abstract}
This study aims to determine and analyze models of coastal villages based on fisheries agribusiness and to assess the status and index of fisheries business sustainability in supporting the development of coastal villages in Donggala Regency, Central Sulawesi. Sampling in this study consisted of the main actors and fisheries business actors in Donggala Regency. Sustainability status will be analyzed using Rapfish with five dimensions developed at the target location based on considerations that can reflect existing conditions. The results show that the sustainability of fishery resource utilization in the Coastal District of Donggala from the five dimensions is shown in the kite diagram which a whole is in the range of $25-50 \%$ indicating that the sustainability status of fisheries business in the Coastal District of Donggala is less sustainable. The lack of attention to the preservation of ecosystems and supported by the increasing activity in coastal areas (land and water) causes the low income of fishermen to catch fish and fish cultivators thus threatening the sustainability of resources.
\end{abstract}

\section{KEY WORDS}

Fisheries, business, sustainability, resources.

Fisheries resources include fish resources, environmental resources, and man-made resources that are used to utilize fish resources. Therefore, management of fisheries resources includes structuring the utilization of fish resources and managing the environment and human activities. In a way, fisheries resource management can be defined as management of human activities in utilizing fish resources (Nikijuluw, 2002).

The link between the needs and use of lands in coastal villages is evident in the application of land conservation and regional development. Therefore, the development of coastal villages is a strategic effort that is very much needed and is closely related to solving current and future rural problems. This effort requires basic information and data on the development of each village. The geographical-ecological condition of a coastal village influences the economic activities in it. Economic activities in coastal villages are characterized by the utilization of coastal environmental resources and services. The economic activities include fisheries, trade, marine tourism, and transportation (Kusumastanto, 2003).

The high level of economic development in the city that reaches the coastal area should have a positive impact on the level of welfare of the community, but this development is often not equally felt by all communities, especially those in the coastal villages. This is partly due to the suboptimal policies governing the direction of the development of coastal villages. Thus efforts need to be made to overcome the above conditions. At least a policy is needed to direct coastal villages into one of the bases for regional development. Consequently the existence of infrastructure (social and economic overhead capital) as a basis for village services can internally and externally encourage the dynamics of the coastal village development.

Minapolitan area is an economic zone that consists solely of production and trade of marine and fisheries commodities, services, housing and other related activities. The concept of Minapolitan is basically the concept of village development that focuses on the 
leading commodities in the fisheries sector in a coastal village. The failure of the development model in an area generally causes the economy in the area to not grow, thus hampering its development.

Donggala Regency is one of the regions in Central Sulawesi Province which is geographically located at 00,30 " N, 20, 20" S and 119o, 45 "-121o, 45" E with an area of $5,275.69 \mathrm{~km} 2$ (BPS Donggala Regency, 2014). Based on data in the 2011-2031 Donggala Spatial Plan, this area has considerable natural resource potential, including plantation, industry, tourism, fisheries, mining, and forest area. The diversity of natural resources possessed by the Regency of Donggala makes this area rich in natural resources. One of them is the coastal and marine areas which have a $435.2 \mathrm{~km}$ coastline, both sides of which consist of 169 villages, with 79 of them coastal villages (BPS, 2016). The potential of marine and fisheries in Doggala Regency can produce 929,700 tons per year, but its utilization is still around 68,000 tons per year. Based on the potential of these fishery resources, the Donggala Regency was determined as one of the areas entitled to receive central government assistance through the Minapolitan program of the Ministry of Maritime Affairs and Fisheries Number KEP.32 / MEN / 2010. The Minapolitan program is more directed at efforts to develop regional-based fisheries and marine businesses. Since 2011 this program has been running in Balaesang District and its surrounding areas for Minapolitan capture fisheries and in South Banawa District and its surrounding areas for Minapolitan aquaculture.

Striving for the sustainability of fisheries resources is one of the most important and strategic steps in supporting fishing businesses in coastal villages, ranging from small to medium scale. Gradually, this effort will encourage the agribusiness chain in the region to become more solid because it not only increases the added value but also absorbs labor and increases income and welfare of the community. With the development of (upstreamdownstream) fisheries agribusiness chains in the coastal villages of Donggala Regency, the community's economy will improve. This can be a capital and an indicator of the success of the (coastal) village development.

Based on the background stated above, this study generally aims to analyze the fisheries-agribusiness based model of sustainable coastal villages. Specifically, this study aims to assess and determine the status and index of fisheries business sustainability in supporting the development of a coastal village model in Donggala, Central Sulawesi.

\section{MATERIALS AND METHODS OF RESEARCH}

This research was conducted through a survey using the Developmental Research method. This was done as an effort to obtain general information about the situation of potential coastal villages to be developed. Therefore, this research utilized many primary data obtained from the survey. Secondary data was used only as a support.

The variables measured in this study are the variables needed for the development of coastal villages, namely: 1) data of areas considered to have the potential to be developed; 2) regional economic data; 3) social and population data; and 4) ecological, infrastructure and institutional data.

This research was carried out in several coastal villages in Donggala Regency that had been designated as research locations after being chosen deliberately (through purposive sampling) from 16 districts with the following considerations: (1) the geographical location borders directly with the waters of the Makassar Strait; (2) the sub-districts, based on the stipulation of the Ministry of Maritime Affairs and Fisheries of the Republic of Indonesia, are included in the Minapolitan area, both of fisheries and aquaculture in Donggala Regency (3) these sub-districts are in synergy with the fisheries and marine development program launched by the Regional Government of Donggala Regency.

The collected data consisted of primary data and secondary data. Secondary data was obtained through literature study, documents in several related institutions and the results of previous research studies, while primary data was obtained from the main actors, namely business actors who were used as respondents, who were broadly interpreted as fisheries agribusiness actors in the coastal villages of Donggala Regency, including those involved in 
procurement and distribution of fishery business production facilities (capture, cultivation, processing , marine tourism and environmental services), primary production activities, processing activities and marketing activities.

The stages of this research include:

1. Determining the number of respondents and sample villages. Overall, the main actors in fisheries and maritime activities in Donggala District in 2015 were 9,038 production households (Department of Maritime Affairs and Fisheries of Donggala Regency, 2015). With the Slovin formula, 383 respondents were obtained, and with a multi-stage sampling method, 35 coastal villages were obtained as samples that were targeted for research;

2. Conducting field surveys / identification to obtain data and determine real problems in the development of coastal villages and constructing problem formulation;

3. Collecting data through literature study sourced from reading material, references and publication of scientific journals, observations, and in-depth interviews using questionnaire guides.

Data analysis in this study was conducted using a sustainability status analysis approach. Sustainability status analysis is an analysis of key factors / lever attributes using the Multi-Dimensional Scaling (MDS) method, which is a simple approach that can be used to evaluate and determine the status and index of sustainability through comparative sustainability of fisheries based on a number of attributes that are easily assessed (Kavanag, 2004; Fauzi and Anna, 2002) and approach with RAp-Bangdesir (Rapid Appraisal of Coastal Village Development in Donggala Regency). This method is a modification of the RAPFISH (Rapid Assessment Technique for Fisheries) program. The results of this study are expected to be considered in formulating the policies on the development of coastal villages in Donggala Regency. Data analysis with MDS includes aspects of sustainability from the dimensions of ecology, economics, technology and infrastructure, institutions, and moral attitudes.

This analysis includes the ordination technique in multivariate statistics with the multidimensional scaling (MDS) method using the Euclidian distance as a basis for calculation. To assess the sustainability of fisheries business in Donggala Regency, the Rapfish program was used with five dimensions developed at the research location based on the consideration that these dimensions can reflect the existing conditions. Based on the various findings, a study was conducted in the form of a model recommendation on fisheries business policies in support of a coastal village model in Donggala Regency based on scientific evidence and information obtained at the study site.

At the stage of data collection for sustainability analysis, the RAPFISH (the Rapid Appraisal of the Status of Fisheries) algorithm of the Multi-dimensional Scaling (MDS) method was used to determine the sustainability status of fisheries resource utilization based on a sustainability index that was assessed based on two reference points, namely a "good" point with a score of $100 \%$ which shows that an attribute reflects conditions that support sustainable fisheries and a "bad" point with a score of $0 \%$ which indicates that an attribute reflects conditions that do not support sustainable fisheries.

The ordination technique (distance determination) in MDS that is based on the Euclidian distance in an n-dimensional space can be written as follows:

$$
d=\sqrt{\mid}\left(x_{1}-\left.x_{2}\right|^{2}+y_{1}-\left.y_{2}\right|^{2}+z_{1}-\left.z_{2}\right|^{2}+. .\right)
$$

The configuration or ordination of an object or point in MDS was then approximated by regressing the Eculidian distance $\left(d_{i j}\right)$ from point $\mathrm{i}$ to point $\mathrm{j}$ with the origin $\left(\delta_{i j}\right)$ as in the following equation:

$$
d_{i j}=\alpha+\beta \delta_{i j}+\varepsilon
$$


In assessing the sustainability index of fisheries resource utilization, each category consisting of several attributes was given a score. Scores were generally ranked between 0 and 4 . The score results were entered into a matrix table with $i$ as the row that represents the fisheries resource utilization category and $\mathrm{j}$ as the column that presents the attribute score.

The ALSCAL method optimizes the square distance $\left(d_{i j}\right)$ to the origin $\left(0_{i j k}\right)$, which in five dimensions ( $\mathrm{i}, \mathrm{j}, \mathrm{k}$ ) is written in the following S-Stress formula:

$$
S=\sqrt{\frac{1}{m}} \sum_{k=i}^{m}\left[\frac{\sum_{i} \sum_{j}\left(d_{i j k}^{2}-O_{i j k}^{2}\right)^{2}}{\sum_{i} \sum_{j} O_{i j k}^{4}}\right]
$$

Where the square distance is the weighted Euclidian distance or what is written as:

$$
d_{i j k}^{2}=\sum_{a=1}^{r} \mathrm{w}_{k a}\left(x_{i a}-x_{j a}\right)^{2}
$$

Rapfish software is an MDS development contained in the SPSS software for the process of rotation (flipping) and some sensitivity analysis that has been integrated in single software. Through this MDS, the position of the point of sustainability can be visualized in two dimensions (horizontal and vertical axes). To project these points on a horizontal line, a rotation was carried out, with the extreme "bad" point having a score of $0 \%$ and the extreme "good" point having a score of $100 \%$. The position of the sustainability status under review will be between these two extreme points. This score is the current index of the sustainability of fisheries resource utilization in Donggala Regency.

\begin{tabular}{|c|c|c|c|}
\hline No & Research Aspects & & The attributes and data requirements \\
\hline 1 & Ecology & $\begin{array}{l}1 . \\
2 . \\
3 . \\
4 . \\
5 . \\
6 . \\
7\end{array}$ & $\begin{array}{l}\text { Environmental quality of coastal resources } \\
\text { Pressure on the waters } \\
\text { Species diversity } \\
\text { Land Use Change } \\
\text { Residents living in coastal villages } \\
\text { Dependence on fisheries as a source of income } \\
\text { Land / water zone }\end{array}$ \\
\hline II & Economy & $\begin{array}{l}8 . \\
9 . \\
10 . \\
11 . \\
12 . \\
13 . \\
14 .\end{array}$ & $\begin{array}{l}\text { Fishery income } \\
\text { Growth in Marketing of fishery products } \\
\text { Growth of fishery product processing business } \\
\text { Capital group business growth } \\
\text { Business Unit } \\
\text { Employment } \\
\text { PAD contribution }\end{array}$ \\
\hline III & $\begin{array}{l}\text { Technology and } \\
\text { Infrastructure }\end{array}$ & $\begin{array}{l}15 \\
16 . \\
17 . \\
18 . \\
19 .\end{array}$ & $\begin{array}{l}\text { Technology Mastery Level } \\
\text { Community access in fishing business activities } \\
\text { Supporting facilities and infrastructure / facilities } \\
\text { Availability of the fishing industry } \\
\text { Database availability }\end{array}$ \\
\hline IV & Institutional & $\begin{array}{l}20 . \\
21 . \\
22 \\
23 . \\
24 . \\
25 .\end{array}$ & $\begin{array}{l}\text { Availability of regulations on the use of fisheries resources } \\
\text { Availability of financial institutions } \\
\text { Availability of Social Institutions } \\
\text { Availability of Fisheries Group Institutions } \\
\text { Status and Frequency of Fishermen Conflict } \\
\text { Community empowerment in fisheries activities }\end{array}$ \\
\hline $\mathrm{V}$ & Moral & $\begin{array}{l}26 . \\
27 . \\
28 \\
29 . \\
30 . \\
31 . \\
32 .\end{array}$ & $\begin{array}{l}\text { Family participation in resource use } \\
\text { Level of Compliance / Community knowledge of the environment } \\
\text { Assimilation and accommodation processes } \\
\text { Conventions for interacting with others } \\
\text { Determination of management that is right or wrong } \\
\text { A sense of trust and togetherness } \\
\text { The existence of values }\end{array}$ \\
\hline
\end{tabular}

Table 1 - The attributes and data requirements in Determining Sustainability Status 
The index value of fisheries business sustainability $(B)$ is presented in a score with a basic scale range of $0-100$. If the fishery business studied has a $B>50$, then it is categorized as "sustainable" and if $\mathrm{B}<50$, then it is categorized as "unsustainable". Following Kavanagh and Pitcher (2004), in this study four categories of sustainability status were prepared, namely: if $B<24.9$ then the fishery business is categorized as "unsustainable"; if $25<B$ $<49.9$ then the fishery business is categorized as "less sustainable"; if $50<B<74.9$ then the fishery business is categorized as "quite sustainable", and if B> 75 then the fishery business is categorized as "sustainable".

The sensitivity value of an attribute of a sustainability dimension is measured from changes in root mean square $(\triangle \mathrm{RMS})$ if the attribute is not used in the analysis. The higher the value of $\triangle R M S$ is, the more sensitive the attribute is, and vice versa. The most sensitive attribute in a dimension is the most important factor influencing sustainability so it is worthy of attention by fisheries business managers (Kavanagh and Pitcher 2004; Fauzi and Anna 2002).

The analysis in this study will go through the following 6 (six) stages:

1. Determination and Review of Attributes;

2. Making of Attribute Scores;

3. Rapfish Ordination;

4. Sustainability Status Index Scale;

5. Sensitivity Analysis;

6. Monte Carlo Analysis.

The attributes and data analysis requirements are shown in table 1.

\section{RESULTS AND DISCUSSION}

Makassar Strait, which is included in the legal territory of Donggala Regency, has various economic activities, such as inter-island sea transportation, capture fisheries, aquaculture and various sand mining activities. Sand mining activities are mostly carried out by business actors in the real sector. Agricultural products from Donggala Regency such as bananas, chilies and tomatoes and plantation products such as coconut are sent to Kalimantan Island. From Kalimantan Island, Donggala Regency receives fishery products such as salted fish.

Administratively, Donggala Regency has 16 sub-districts with 167 villages / subdistricts and a total area of 5,275.69 Km2, with the following administrative boundaries:

- Tolitoli Regency in the north;

- West Sulawesi Province, Sigi Regency and Palu City in the south;

- West Sulawesi Province in the west;

- Sigi Regency and Parigi Moutong Regency in the east.

The area of Donggala Regency, according to distribution per district, gives an illustration in seeing the area of each district. It should be noted that of the 16 districts in Donggala Regency, 14 of them are located in the coastal area and 2 (two) others, namely Rio Pakava District and Pinembani District, are located in the mountainous area.

This region is classified as an agricultural region so agriculture has a dominant role in the structure of the economy. The contribution of the agricultural sector to the Gross Regional Domestic Product (GRDP) was above $37.72 \%$ or as much as Rp.3,041,177.00 million in 2015. Overall the GRDP of Donggala Regency continues to increase from year to year. This shows that Donggala Regency has experienced a phase of regional development which is marked by the shifting of the role of the primary sector, replaced by the secondary and tertiary sectors.

The potential fish resources in the Makassar Strait, including the waters of Donggala Regency which, according to data from the Directorate of Research and Exploration of Biological Resources of the Indonesian Ministry of Maritime Affairs and Fisheries (2014), are included in the Fisheries Management Areas (WPP) 713 (Makassar Strait and Flores Sea) 
category, include large pelagic fish, small pelagic fish, demersal fish, reef fish for consumption, peneid shrimp, lobsters, squid and ornamental fish.

The potential of marine fisheries in Donggala Regency is in the Districts of Banawa, South Banawa, Labuan, Tanantovea, Sindue, Sirenja, Balaesang, Balaesang Tanjung, Damsol, Sojol and North Sojol. Meanwhile, inland fisheries are spread evenly in all districts except Pinembani and Rio Pakava Districts. Fisheries production, both marine and inland, in Donggala Regency experienced a significant decrease in 2015 compared to 2014. Almost all districts experienced a decline, except Banawa District, which actually saw its fisheries production increasing from 1,947.29 tons to 3,150 tons in 2015.

Table 2 - Fisheries Production in sub-districts and sub-sectors in Donggala district (tons), 2014-2015

\begin{tabular}{|c|c|c|c|c|c|c|c|}
\hline \multirow{2}{*}{ No } & \multirow{2}{*}{ District } & \multicolumn{2}{|c|}{ Sea Fisheries } & \multicolumn{2}{|c|}{ Public Water } & \multicolumn{2}{|c|}{ Total Amount } \\
\hline & & 2014 & 2015 & 2014 & 2015 & 2014 & 2015 \\
\hline 1 & Rio Pakava & - & - & - & - & - & - \\
\hline 2 & Pinembani & - & - & - & - & - & - \\
\hline 3 & Banawa & 1.947 .26 & 3150.00 & - & - & 1947.26 & 3150.00 \\
\hline 4 & Banawa Selatan & 2.461 .23 & 1220.00 & - & - & 2461.23 & 1220.00 \\
\hline 5 & Banawa Tengah & 1.924 .57 & 1033.00 & - & - & 1924.67 & 1033.00 \\
\hline 6 & Labuan & 222.81 & 162.00 & - & - & 222.81 & 162.00 \\
\hline 7 & Tanantovea & 926.53 & 589.00 & - & - & 926.53 & 589.00 \\
\hline 8 & Sindue & 283.42 & 182.00 & - & - & 283.42 & 182.00 \\
\hline 9 & Sindue Tambosabora & 1.624 .85 & 1014.00 & - & - & 1624.85 & 1014.00 \\
\hline 10 & Sindue Tobata & 1.916 .60 & 1263.00 & - & - & 1916.60 & 1263.00 \\
\hline 11 & Sirenja & 3.299 .44 & 2151.00 & - & - & 3299.44 & 2151.00 \\
\hline 12 & Balaesang & 3.376 .73 & 2127.00 & - & - & 3376.73 & 2127.00 \\
\hline 13 & Balaesang & 3.56 .44 & 2024.00 & 391.66 & 37.80 & 3958.10 & 2061.80 \\
\hline 14 & Dampelas & 1.401 .38 & 884.00 & 479.66 & 42.70 & 1881.04 & 926.70 \\
\hline 15 & Sojol & 1.329 .18 & 846.00 & - & - & 1329.18 & 846.00 \\
\hline \multirow[t]{2}{*}{16} & Sojol Utara & 1.051 .49 & 1350.00 & - & - & 1051.49 & 1350.00 \\
\hline & Donggala & 25.332 .03 & 17995 & 871.32 & 80,5 & 26.203 .35 & 18.075 .5 \\
\hline
\end{tabular}

Source: DKP of Donggala Regency, 2016.

Fishery activities are related to efforts to utilize fishery resources through fishing business at certain fishing times and areas. The form of fisheries business management that is carried out by fishermen is an individual business. Individual fishing business activities are mostly carried out along the coast of Donggala Regency with the fishermen departing at dawn around $03.00 \mathrm{am}$ and returning at noon at 2:00 pm. The catches of these small fishermen are generally sold around the area where they live at relatively low prices.

In fisheries business management, almost all household members are involved, except in fishing activities at Purse Seine. In the Bajo ethnic group who generally use fishing gear in the traditional way, all family members including those who have entered school age are directly involved in fishing. In some Kaili ethnicities, when women are not involved in fishing, then they sell the catches to the market or take part in the processing of the catches.

In the coastal area of Donggala there is a pattern of work and business relations, where the dependence of fishermen on middlemen ("Padola or" Boss ") is still very clear and dominant. The working relationship between the capital owners (padola) and the fishermen appears as an unbalanced relationship which only strengthens the position and facilitates the activities of the capital owners, who in this case act as employers. This relationship is influenced and shaped by certain conditions prevailing in fishing communities, causing the employers to have a stronger position and greater power than the fishermen. This relationship can make fishermen even poorer. It is this relationship that needs attention from the government so that the link between padola and small fishermen can be eliminated.

Various capture fisheries businesses, from modern to small scales, operate along the waters of Donggala Regency. The diversity of these types of businesses depends on the size of the fishermen's capital as well as their business opportunities. Large capital owners will certainly choose to develop their fishing business, for example by buying a 20 GT purse seine boat, a chart fishing gear, a 1-5 GT long line tuna boat, and a floating net cage. While 


\section{RJOAS, 10(106), October 2020}

fishermen with small capital will choose to pursue a small-scale fishery business using fishing gear, gillnet, sero and bubu.

The type of capture fisheries business carried out by fishermen in the Donggala Regency region is relatively homogeneous. For example some of their fishing gear have production systems that are classified as small / traditional. Table 3 above illustrates the general classification of modern and small scale fisheries business types. The Purse Seine, Bagan, and Tuna Long line fishing businesses are included in the modern category, while Pancing Ulur, Gillnet, sero and bubu are small scale businesses.

Of the 14 districts in the coastal area of Donggala Regency, 6 of them have the potential for the development of aquaculture, namely: South Banawa District with seaweed and brackish cultivation; Balaesang District with brackish water cultivation; Balaesang Tanjung District with Lake Rano covering an area of +296.2 ha that has the potential for freshwater cultivation; and Dampelas District with Lake Talaga covering an area of +542.6 ha that has the potential for freshwater cultivation.

Table 3 - Cultivation Area by District in Donggala Regency 2014

\begin{tabular}{llll}
\hline No & District & Potential Land $(\mathrm{Ha})$ & Treated Land (ha) \\
\hline 1. & Banawa Selatan & 1.523 & 574 \\
2. & Balaesang & 165 & 108 \\
3. & Balaesang tanjung & 421.2 & 123 \\
4. & Damsol & 616.6 & 590.5 \\
5. & Sojol & 620 & 605 \\
6. & Sojol Utara & 125 & 120 \\
\hline amount & & 3.470 .8 & 2.118 .5 \\
\hline
\end{tabular}

Source: DKP of Donggala Regency, 2015.

Aquaculture production in 2014 was $5,875.45$ tons, consisting of 1,879 tons of seaweed production, 3,965 tons of milkfish and shrimp production, and 13.45 tons of carp and tilapia production with an area of 2,079 ha of cultivation consisting of brackish cultivation (seaweed) and fresh water (DKP Donggala district, 2015). Seaweed cultivation is marketed in a dry state to the City of Palu and West Sulawesi Province.

Table 4 - Number Development of Fisheries Households by District and Sub-Sector in Donggala Regency 2014-2015

\begin{tabular}{|c|c|c|c|c|c|c|c|}
\hline \multirow{2}{*}{ No } & \multirow{2}{*}{ District } & \multicolumn{2}{|c|}{ Sea Fisheries } & \multicolumn{2}{|c|}{ Public Water } & \multicolumn{2}{|c|}{ Total Amount } \\
\hline & & 2014 & 2015 & 2014 & 2015 & 2014 & 2015 \\
\hline 1 & Rio Pakava & - & - & - & - & - & - \\
\hline 2 & Pinembani & - & - & - & - & - & - \\
\hline 3 & Banawa & 1.612 & 1610 & - & - & 1612 & 1610 \\
\hline 4 & Banawa & 690 & 679 & - & - & 690 & 679 \\
\hline 5 & Banawa & 233 & 208 & - & - & 233 & 208 \\
\hline 6 & Labuan & 222 & 223 & - & - & 222 & 223 \\
\hline 7 & Tanantovea & 338 & 334 & - & - & 338 & 334 \\
\hline 8 & Sindue & 895 & 895 & - & - & 895 & 895 \\
\hline 9 & Sindue & 452 & 452 & - & - & 452 & 452 \\
\hline 10 & Sindue Tobata & 335 & 335 & - & - & 335 & 335 \\
\hline 11 & Sirenja & 1.001 & 554 & - & - & 1001 & 554 \\
\hline 12 & Balaesang & 1.142 & 1142 & - & - & 1142 & 1142 \\
\hline 13 & Balaesang & 698 & 698 & 52 & 52 & 750 & 750 \\
\hline 14 & Dampelas & 665 & 665 & 27 & 39 & 692 & 704 \\
\hline 15 & Sojol & 756 & 756 & - & - & 756 & 756 \\
\hline \multirow[t]{2}{*}{16} & Sojol Utara & 396.0 & 396 & - & - & 396 & 396 \\
\hline & Donggala & 9.435 & 8947 & 79 & 91 & 9514 & 9038 \\
\hline
\end{tabular}

Source: Donggala Regency in Figures, 2016.

Along with the development of this fishery business, there is a decline in the number of fisheries production households. This happens because many members of the coastal community turn to other jobs such as gardening, becoming builders and working in urban 
RJOAS, 10(106), October 2020

areas. However, production remains available and sustainable because it is supported by the equipment and technology used by some of the fishermen and fish farmers.

Index and Status of Fisheries Business Sustainability. The waters on the coast of Donggala Regency are fishing and cultivation areas, but with the development of socioeconomic and development activities, the infrastructure (such as the port) in the vicinity has caused the access of coastal communities such as the fishermen to be increasingly limited. In addition to fishing, other economic activities that take place on the coast of Donggala Regency include aquaculture, fishery product processing, marine tourism equipped with restaurants, and lodging / hotels in the coastal area and fisheries industry activities in several districts. The traffic of commercial vessels in and out of the port of goods (Donggala and Wani) and fish landing bases (Donggala) reduces the space for fishermen when they fish in the waters of the Donggala district. This study of the sustainability status of fisheries business in Donggala Regency includes an analysis of five dimensions of resource sustainability, namely ecology, economics, technology and infrastructure, institutions, and moral.

Index Value and Sustainability Status in Ecology Dimension. The ecological dimension is the main indicator in evaluating the sustainability status of fisheries business and indicates the good or bad quality of the environment and fisheries resources along with the natural processes in them, both those that can or cannot sustainably support any economic activity undertaken in the utilization of fisheries resources. Utilization of fisheries resources in the Coastal District of Donggala will be biased and lead to destructive conditions if not based on applicable rules and environmental understanding that can guarantee the sustainability of the resource. Sustainability indicators refer to the indicators developed by FAO in the context of implementing the 1995 CCRF. The meaning of this dimension in the framework of sustainable fisheries development is translated into 7 (seven) attributes, namely the quality of the environment of coastal resources, pressure on waters, species diversity, land use change, poor people who live in coastal areas, dependence on fisheries as a source of income, and land / water designation zones. Operationally these attributes can describe the condition of fisheries in the Coastal District of Donggala.

Based on the results of the Rapfish ordinance analysis, it is known that the ecological dimension sustainability index value is 43.55 . This value is in the range of 25-49.9 (Figure 1). This condition indicates that the fisheries business carried out by the coastal community in Donggala Regency is in a "less sustainable" status. From the sensitivity analysis aimed at looking at its effect on the resource sustainability score based on the ecology dimension with the leverage analysis method of 7 attributes, three attributes were found to be most sensitive to the sustainability of fisheries business in the Coastal District of Donggala, namely species diversity, pressure on waters and dependence on fisheries as source of living. Changes to the 3 leverage factors will easily influence the increase or decrease of the sustainability index value based on the ecological dimension. The results of the leverage analysis are presented in Figure 2.

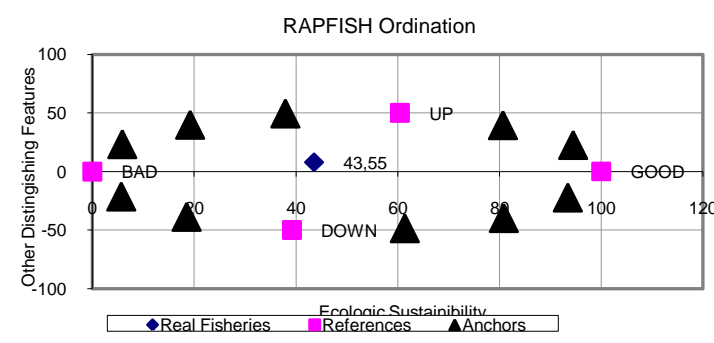

Figure 1 - Position Index Value and Sustainability Status of Fisheries in the Ecological Dimension on the Coastal District of Donggala

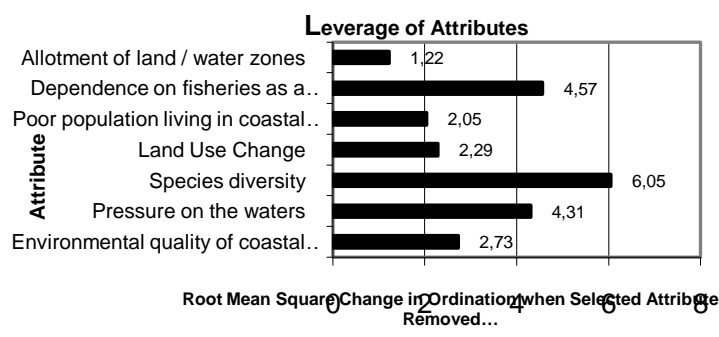

Figure 2 - Sensitivity Values of Ecological Dimension Attributes Expressed in Changes in Root Mean Square (RMS) Sustainability Scale 0-100 
Based on the results of the leverage analysis above, it appears that the attributes of species diversity that are available and cultivated by the main business actors have the highest RMS value, which is 6.06. This can be interpreted that these attributes have the greatest influence on the sustainability of fisheries resource utilization from the ecology standpoint. Overall, the coast of Donggala Regency was once a fishing ground. But along with the development of the region, many ports were built in the waters of the Makassar Strait with the consideration that the strait is an area with the most resources. In addition, a factor that is considered to have an impact on changes in access to fishing areas is the presence of ports. So far there are two goods ports (in Donggala and Wani) and one fish landing base (in Donggala).

In addition to activities at sea, activities on land also increases. This can be seen from the emergence of several business sectors, such as the $C$ mining quarry, tourist attractions (restaurants, inns and hotels) and industrial estates in the northern part of Donggala Regency. The development of marine tourism in the coastal area of Donggala Regency is increasingly widespread, because this area does have its own uniqueness, with it being surrounded by mountains and (white sand) beaches which makes the interest of the people of Palu and surrounding areas to travel in the region increasingly high.

Besides having a positive impact on the people's welfare and local revenue, these activities can also have a negative impact on the region's ecosystem, both directly and indirectly. In addition, water pollution will affect fishery activities because it can reduce aquatic productivity, cause damage to habitat, and reduce the quality of the aquatic environment as a medium for fish life. This will reduce the habitat of fish resources.

The negative effect of the above activities can be seen from the decline in the production of catches of fishermen and fish farmers in Donggala Regency in the last five years (2011-2016). Based on statistical data in 2016, the production of catches in Donggala Regency in 2014 was 26,203.35 tons, and it dropped to 18,075,5.5 tons in 2015.

Index Value and Sustainability Status in Economy Dimension. This dimension reflects the success or failure of a fisheries resource utilization activity in the Coastal District of Donggala in obtaining results that are economically viable in the long term and in a sustainable manner. In this dimension, 7 (seven) attributes were developed that can describe the condition of fisheries in the study location, namely fishery product revenue, fishery product marketing business growth, fishery product processing business growth, business group capital growth, mina business units, employment, and contribution to Regional Original Revenue.

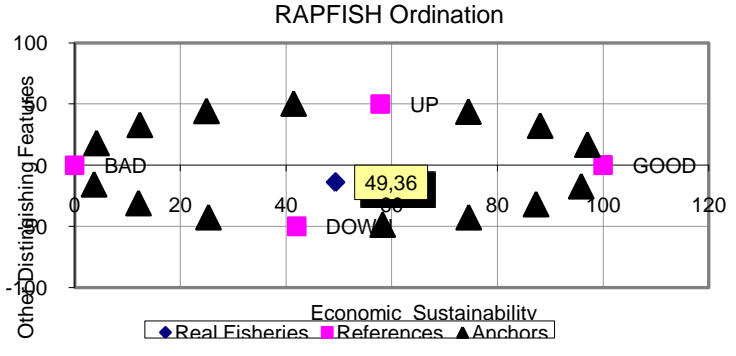

Figure 3 - Position Index Value and Sustainability Status of Fisheries in the Economic Dimension

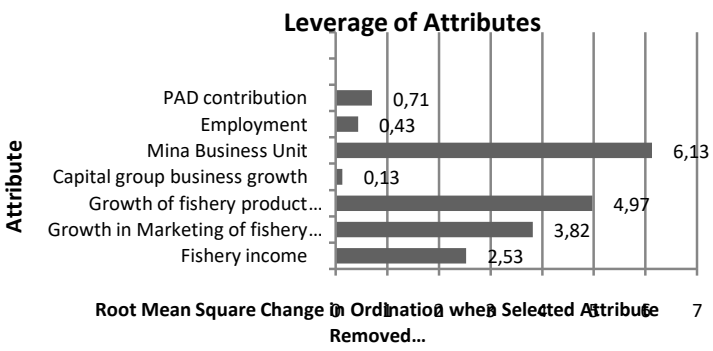

Figure 4 - Sensitivity Value of Economic Dimension Attributes Expressed in Change in Root Mean Square (RMS) Sustainability Scale 0-100

The results of the analysis using Rapfish software on the economic dimension show that the index value of the economic dimension of fishermen's sustainability is 49.36. This value is in the range of 25-49.9 which indicates the 'less sustainable' status as presented in Figure 3. The results of the leverage analysis as presented in Figure 4 show that the attribute of the Mina business unit has the highest RMS value, which is 6.13 , followed by the attribute the growth of the yield processing unit with a value of RMS 4.97. This can be interpreted that these attributes have the most influence on the sustainability of fisheries 
resource utilization in terms of the community's economy. The economic dimension study was conducted to be able to allocate fishery resources with economic carrying capacity efficiently, namely how to use fish resources to increase financial benefits and increase the growth of the mina business unit while maintaining economic growth.

Based on the results of this study, it was revealed that the net income level of traditional fishing communities varies greatly, i.e. between $R p 300,000$ and $R p 900,000$ per month. This figure is still below the 2016 Central Sulawesi Province minimum wage of Rp1,455,000. In general, the economic activities of fishermen in the Coastal District of Donggala are fluctuating due to their dependence on fisheries productivity. If productivity is high (fishing season), then their income will increase but people's purchasing power decreases; and vice versa. Fishermen's dependence of on the season greatly affects their income every time they conduct fishing activities.

The level of income from the fishery business determines the welfare of fishermen and other major business actors, which play an important role in conditioning economic growth in the coastal area of Donggala Regency. Utilization of fisheries resources is directed at increasing the welfare of fishermen, improving the community's economy, creating jobs and increasing the receipt of Regional Original Revenue from the fisheries and marine sector.

Index Value and Sustainability Status in Infrastructure and Technology Dimension. The dimension of technology and infrastructure sustainability is an effort that is driven by economic motives to meet the needs to improve community business operations. This dimension is a reflection of the degree of utilization of fisheries resources using technology. Evaluation of the attributes developed on the technology and infrastructure dimensions is translated into 5 (five) attributes that technically describe the condition of the technology used and the means of supporting fisheries in the Coastal District of Donggala. The five attributes are the level of technological mastery, community access in fisheries business activities, support for facilities and infrastructure, availability of the fishing industry, availability of databases.

Based on the analysis using Rapfish software on the technology dimension, it is known that the value of the sustainability index of this dimension is 34.78 . This value is in the range of 25-49.9 which indicates the status of "less sustainable" as presented in Figure 6. From the sensitivity analysis on the dimensions of the fishing unit using the leverage analysis method of 5 attributes, three sensitive attributes were obtained (Figure 5), namely the availability of the fishing industry, the availability of a database and the support of facilities and infrastructure. Changes to the 3 leverage factors will very easily affect the increase or decrease in the value of the technological and infrastructure dimensions of the sustainability index.

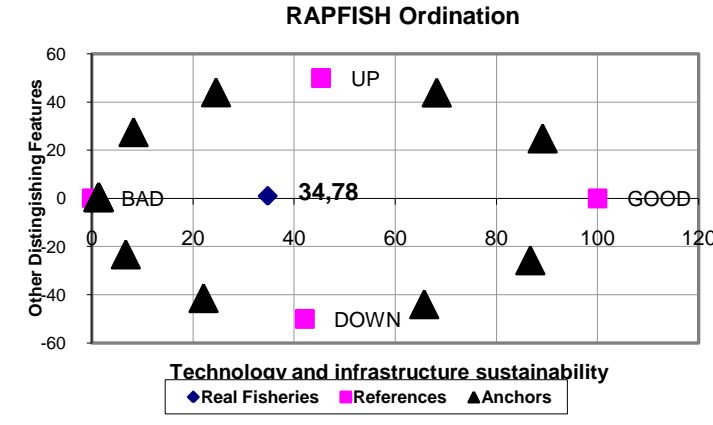

Figure 5 - Position Index Value and Sustainability Status of Fisheries in the Technology and Infrastructure Dimensions

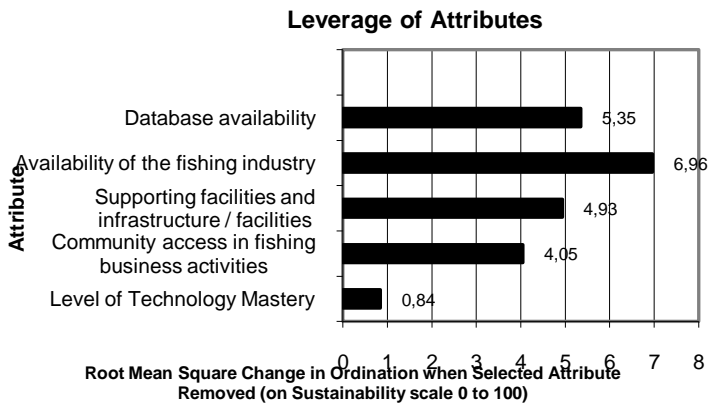

Figure 6 - Sensitivity Value of the Attributes of Technology and Infrastructure Dimensions Declared in the Change in Root Mean Square (RMS) Sustainability Scale 0-100

The results of the leverage analysis above indicate that the attribute of fishing industry availability has the highest RMS value, which is 6.96. This can be interpreted that this attribute has the most influence on the sustainability of fisheries resource utilization in terms 
of technology and infrastructure. The available infrastructure facilities for the fisheries industry, including those in small scale (households), such as the Fish Markets, have been utilized by fishermen and fish farmers in the Coastal District of Donggala. This condition indicates that fisheries business activities, both in small and medium scale, have been going well.

In general, the technology used in fisheries business activities in the Coastal District of Donggala has not shown significant development due to limited capital and low human resource capacity so that the transfer of technological knowledge moves very slowly. This condition also limits the scope of operation for fishing and aquaculture operations and other businesses in fisheries. Because most of it is focused on coastal waters, the management of fish resources in the Makassar Strait waters by fishing fleets is relatively low.

Index Value and Sustainability Status in Institutional Dimension. The dimension of community institutions describes what the institutional system looks like at the level of human safety and the environment in the management of the human resources it contains. Better arrangements can guarantee that any economic activity in the fisheries sector can last in the long run and in a sustainable manner. Fisheries business activities are inseparable from the social conditions of the fishing and cultivator communities as well as businesses that carry out the utilization of these fish resources. This dimension also provides an overview of the existing institutional system and indicates whether a resource use activity is long-term and economically sustainable. In this dimension, 6 (six) attributes that can describe institutional conditions in community businesses in the Coastal District of Donggala were developed, including the availability of regulations on the use of fishery resources, the availability of financial institutions, the availability of social institutions, the availability of fisheries group institutions, the status and frequency of fishermen conflicts, and community empowerment in fisheries activities.

The results of the analysis using Rapfish software on this institutional dimension showed that the value of the sustainability index of the institutional dimension was 41.90 . This value is in the range of 25-49.9 which indicates the status of 'less sustainable' as shown in Figure 8 below. Based on the results of the leverage analysis, it appears that the attribute of the fisheries business group availability has the highest RMS value, which is 2.56 . This can be interpreted that this attribute has the most influence on the sustainability of fisheries resource utilization from an institutional standpoint.

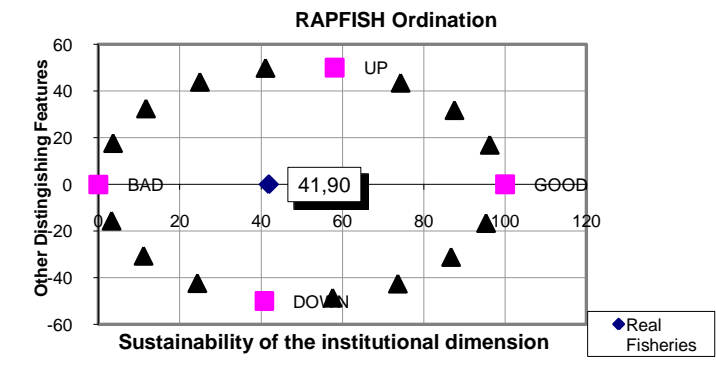

Figure 7 - Position Index Value and Sustainability Status of Fisheries in the Institutional Dimension

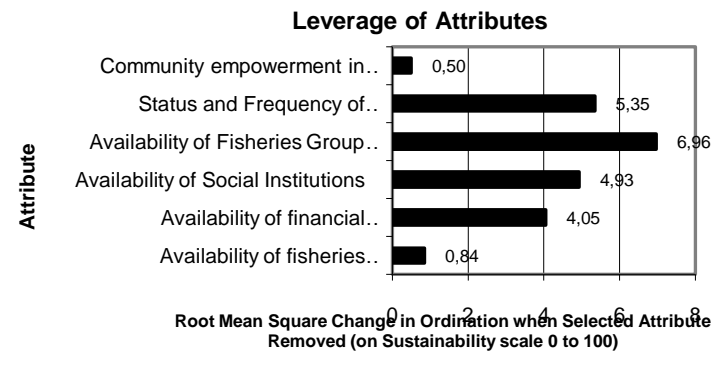

Figure 8 - Sensitivity Value of Institutional Dimension Attributed in Change of Root Mean Square (RMS) Sustainability Scale 0-100

The lack of catches, seizure of fishing areas, gaps in the control of fishing units, different interpretations of existing laws and regulations, and lack of optimal supervision and law enforcement are considered as triggering factors for conflicts that occur between fishermen so far. In addition, the lack of synergy between the fisheries sub-sector and the tourism sub-sector led to overlapping of boat mooring areas and areas developed as tourist attractions, triggering disputes.

Local governments have greater responsibility in coastal community empowerment programs because they know their communities better and understand the problems they face. However, non-governmental parties, such as the community itself, the business world, 
non-governmental organizations and universities, also have responsibilities in empowering coastal communities. Regional regulations in the field of fisheries issued by the local government of Donggala Regency generally still reflect the dominant economic interests. In other words, regional regulations that provide ecological protection are still lacking. Therefore, the formulation and stipulation of regional regulations concerning the use of resources in the coastal area of Donggala Regency is required. Regional regulations that can be issued include prevention of environmental pollution, recovery of endangered resources, regulation of fishing gear operations and efforts, and regulation of zones and activities in coastal areas.

Index Value and Sustainability Status in Moral Dimension. The status of sustainability in the moral dimension is aimed more at the main actors and business actors. This status illustrates the attitudes of each individual in the customer society in interacting with the aim of creating harmony in work relations, both between the main actors and business actors in a region. If this is not applied in a community environment, a conflict of interest will arise. Fisheries business activities cannot be separated from the conditions and situation of fishing communities, cultivators and fisheries business actors, which often results in misunderstandings in the utilization of these fishery resources. This dimension also provides a picture of the moral attitude between the main actors and business actors in giving space to other parties in order to create a good atmosphere or relationship so that fishery resource utilization activities can run in the long term and in a sustainable manner. In this dimension, 7 (seven) attributes were developed to describe the condition of people's moral attitudes on the Coastal District of Donggala, namely family participation in resource use, level of community compliance / knowledge towards protecting the environment, assimilation and accommodation processes, conventions in interacting with others, determining the correct management, mutual trust and togetherness, and the existence of a value system.

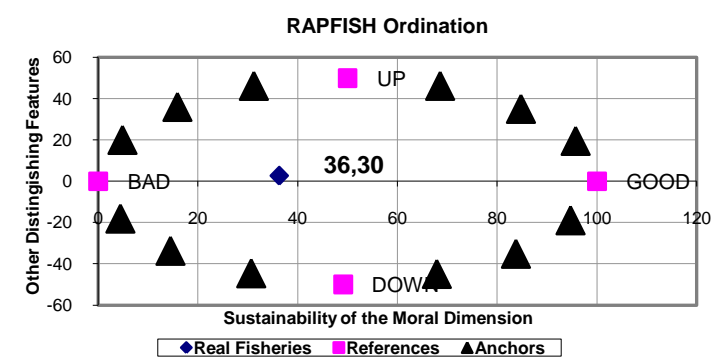

Figure 9 - Position Index Value and Sustainability Status of Fisheries in the Moral Dimension

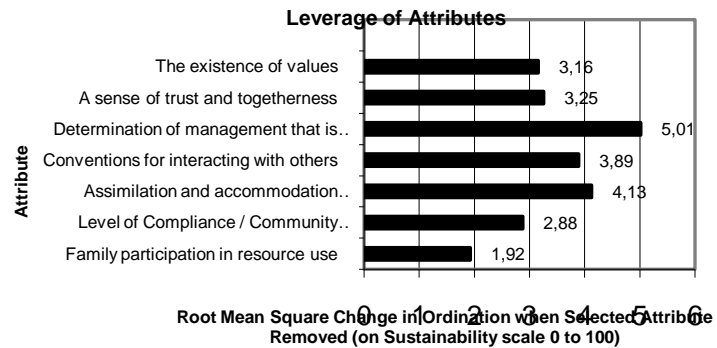

Figure 10 - Sensitivity Value of Moral Dimension Attributed in Change of Root Mean Square (RMS) Sustainability Scale 0-100

The results of the analysis using Rapfish software on this moral dimension show that the index value of the sustainability in moral dimension is 36.30 . This value is in the range of 25-49.9 which indicates the status of 'less sustainable' as presented in Figure 10 below. Based on the results of the analysis of leverage, it appears that the attribute of determining the correct management has the highest RMS value, which is 6.01 . This can be interpreted that this attribute has the most influence on the sustainability of fisheries resource utilization from a moral standpoint.

\section{DISCUSSION OF RESULTS}

The utilization of the coastal area of Donggala Regency is dynamic, and currently, community activities such as fishing, fish cultivation, processing of catches, marine tourism and other environmental services, continue to take place in several coastal areas of Donggala Regency. From the aspect of conservation of fisheries resources, biodiversity and tourism based on natural resources, most types of marine tourism in some coastal villages tend to be uncontrolled and very worrying. 
The results of the analysis of the sustainability of the use of fisheries resources in the Coastal District of Donggala in five dimensions are shown in the kite diagram (Figure 11). The overall scores are in the range of $25-50 \%$, indicating that the status of fisheries in the Coastal District of Donggala is 'less sustainable'. This index value can be improved through improvements to several attributes (variables) that affect the value of the sustainability index, both in the ecological, economic, technological-infrastructure, institutional, and moral dimensions. Sensitive attributes that affect the value of the resource sustainability index need to be addressed immediately, without ignoring attributes that are not or less sensitive based on the results of Leverage analysis. Lack of attention to the preservation of ecosystems and the increasing activity in coastal areas have caused a decline of income from the fishing / cultivating / processing of fish catching and aquaculture activities and can threaten the sustainability of existing resources. This was confirmed by Carlander (1968) who explained that the sustainability of a resource is largely determined by the presence or absence of the biological balance of the resource, i.e. continuous regeneration that is not interrupted by attempts of resource utilization.

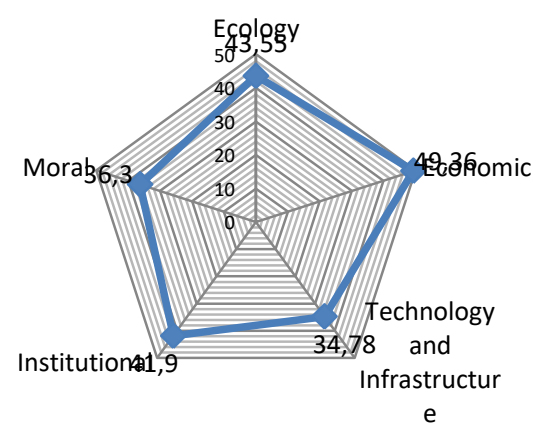
Figure 11 - Flying Chart of Multidimensional Sustainability of Fisheries Resource Utilization
on the Coastal District of Donggala

The ability of each attribute to explain and contribute to the sustainability of the system is assessed by looking at the coefficient of determination (R2) for each analyzed dimension. According to Kavanagh (2001) in Fauzi and Anna (2002), the aspect of uncertainty is caused by several factors, including the impact of errors due to lack of information, the impact of scoring diversity due to differences in ratings, errors in data entry and high stress scores obtained. Determination of the index value and multidimensional sustainability status of the performance of fisheries resource utilization is done by multiplying the index value of each dimension as presented in Table 5.

Table 5 - Index Value, Statistics on Fisheries Resource Utilization in Donggala District

\begin{tabular}{lllll}
\hline Dimension & Index value & Stress & $\mathrm{R}^{2}$ & Number of Iterations \\
\hline Ecology & 43.55 & 0.142 & 0.948 & 2 \\
Economics & 49.36 & 0.146 & 0.942 & 2 \\
Infrastructure Technology & 34.78 & 0.134 & 0.952 & 2 \\
Institutional & 41.90 & 0.139 & 0.94 & 2 \\
Moral & 36.30 & 0.142 & 0.950 & 2 \\
\hline
\end{tabular}

Source: Research Results, 2018. Note: Index values 34.78-49.36 are categorized as less sustainable. Stress value $<0.25$ means goodness of fit. $R 2$ value $95 \%$ or $>95 \%$ : very good contribution.

Alder et al (2000) in Fauzi and Anna, (2002) stated that the stress value is said to be good if it is smaller than $25 \%(S<0.25)$ and the coefficient of determination (R2) shows a very significant value, which is an average of 0.95 with a confidence range of $95 \%$. This means that all the attributes that serve as indicators in this study can reflect the original data 
or the value of goodness of fit in MDS and explain the condition and status of fishery resources in the Coastal District of Donggala.

Table 6 shows that based on the results of the Monte Carlo analysis, the MDS index value did not change too much, with a confidence range of $95 \%$. It can be ascertained that scoring errors, the influence of score variations, the stability of the repeated MDS analysis process, or incorrect data entry or missing data have no effect.

Table 6 - Results of Monte Carlo Analysis Index of Utilization Status of fisheries resources

\begin{tabular}{llll}
\hline Dimensions & RAPFISH & MONTE CARLO & Difference (MDS-MC) \\
\hline Ecology & 43.55 & 43.98 & 0.43 \\
Economics & 49.36 & 47.93 & 1.43 \\
Infrastructure Technology & 34.78 & 37.81 & 3.03 \\
Institutional & 41.90 & 41.74 & 0.16 \\
Moral & 36.30 & 37.53 & 1.23 \\
\hline
\end{tabular}

Source: Research Results, 2018.

Based on the five dimensions studied, fisheries resources utilized by the main actors and business actors in the coastal villages of Donggala Regency can be categorized as worrying (less sustainable). Therefore, improvements to attributes that provide high sensitive values and negative effects must be carried out so that the index value and sustainability status increase. Efforts to overcome the above problems according to the author must be carried out in an integrated and well-coordinated manner by the government of Donggala Regency and the parties concerned. The regional spatial plan of Donggala Regency must consider the sustainability of fisheries businesses that are strengthened by various rules.

\section{CONCLUSION}

The sustainability status of fisheries business based on a study of five dimensions with 32 attributes developed in the utilization of fishery resources in the Coastal District of Donggala shows a less sustainable status (value $<50$ ) where the ecological dimension has an index value of 43.55, an economy with an index value of 49.36, infrastructure technology has an index value 34.70, Institutional with an index value of 41.90 and moral dimenation with an index value of 36.30 .

Some of the lever factors of the 5 sensitive dimensions that need to be maintained and developed include: the ecological dimension; species diversity, dependence on fisheries as a source of income, pressure on water. Economic dimension; business unit, growth of fishery product processing business, growth of yield marketing business. Infrastructure technology dimensions; availability of the fishing industry, availability of databases, support of facilities and infrastructure. Institutional dimension; availability of financial institutions, status and frequency of conflicts, availability of social institutions, moral dimensions; determination of right and wrong management, assimilation and accommodation processes, conventions for interacting with others.

\section{REFERENCES}

1. Arif Satria, 2002. Pengantar Sosiologi Masyarakat Pesisir. Penerbit Pustaka Cidesindo, Jakarta.

2. Badan Pusat Statistik 2016. Kabupaten Donggala dalam Angka Tahun 2016. BPS Kabupaten Donggala.

3. Carlander KD. 1968. Notes on Fishery Management. lowa State University. Unpublished.

4. Chambers, R, 1991 Shortcut and Participatory Method for Gaining Social Information for Project, M Putting People First Ociological Variabels in Rural Development. Oxford University. 
5. Dahuri, R.H. Jacub Rais and Sapta Putra Ginting, 2001 Pengelolaan Sumber Daya Desa pesisir and Lautan Secara Terpadu. Pradnya Paramita. Jakarta.

6. Dinas Pekerjaan Umum Kabupaten Donggala, 2012. Rencana Tata Ruang Desa(RTRW) Tahun 2011-2031. Donggala.

7. Douglass, Mike. 1998. "A Regional Network Strategy for Reciprocal Rural-Urban Linkages: An Agendafor Policy Research with Reference to Indonesia", Third World Planning Review, 20 (1).

8. Eriyatno. 2003. Ilmu Sistem Meningkatkan Mutu and Efektifitas Manajemen. IPB Press. Bogor.

9. Fauzi, A and Anna. S. 2002. Evaluasi Status Keberlanjutan Pembangunan Perikanan: Aplikasi Pendekatan RAPFISH (studi Kasus Perairan Pesisir DKI Jakarta). Jurnal Pesisir and Lautan. 4(3): $43-55$.

10. Fauzi A, Anna S, 2005. Permodelan Sumberdaya Perikanan and kelautan untuk Analisis Kebijakan. Penerbit Gramedia Jakarta.

11. Kavanagh P. Pitcher Tj. 2004. Implementing microsoft excel software for Rapfish: A technique for the rapid appraisal of fisheries status. Fisheries Centre Research Report, $12(2) ; 1-35$.

12. Kusnadi, M.A. 2003 Konflik Sosial Nelayan, Kemiskinan and Perebutan Sumber Daya Perikanan. Yogyakarta LkiS.

13. Kusumastanto, T. 2003. Ocean Policy dalam Membangun Negeri Bahari di Era Otonomi Daerah. Gramedia Pustaka Utama, Jakarta.

14. Moh. Rasyid Ridhoh, 2008. Potensi Sumberdaya Ikan and Arah Pengembangan Desa pesisir Tanjung Jabung Barat Provinsi Jambi; Jurnal Pengelolaan Lingkungan \& SDA, 7(3):148-157.

15. Pitcher TJ, Preikshot D, 2001. RAPFISH; a rapid appraisal technique to evaluate sustainability status of fisheries. Fisheries Research, 49:255-270.

16. Rustiadi, E, S. Saefulhakim, and D.R. Panuju. 2002. Perencanaan Pengembangan Wilayah. Laboratorium Perencanaan Pengembangan Sumberdaya Lahan. Jurusan Tanah, Fakultas Pertanian IPB. Bogor.

17. Sa'id, E.Gumbira and A.Harizt Intan. 2001. Manajemen Agribisnis. Jakarta: Ghalia Indonesia.

18. Sugiyono, 2008. Metode Penelitian Bisnis. CV. Alfabeta, Bandung.

19. Supomo, 2006. Pengembangan Desa pesisir Kabupaten Barru Melalui Klaster Penangkapan Ikan Laut. Jurnal Ekuitas ISSN 1411-0393.

20. Supriadi, D. 2014. Analisis Potensi and Arah pengembangan Desa Pesisir di Kabupaten Batubara; Jurnal Ekonomi, 17(3): 14-27.

21. Thamrin, S. H. Sutjahjo, C. Herison, and S. Biham, 2007. Analisis Keberlanjutan Desa Perbatasan Kalimantan Barat-Malaysia Untuk Pengembangan Kawasan Agropolitan: Studi kasus Kecamatan Bengkayang Dekat Perbatasan Kabupaten Bengkayang). Jurnal Agro Ekonomi. Vol. 25 (2): 103-124.

22. Keputusan Menteri Kelautan and Perikanan No. KEP. 32/MEN /2010, tentang Penetapan Kawasan Minapolitan.

23. Undang-Undang No 29 Tahun 2014 Tentang Perikanan. 